\title{
THE MORPHOGENESIS OF CIRCUMVALLATE PAPILLAE AND THE DIFFERENTIATION OF TASTE BUDS IN THE PORCINE FOETUS FROM DAY 76 TILL BIRTH AND IN THE ADULT PIG
}

\author{
F. TICHÝ \\ Department of Anatomy, Histology and Embryology, University of Veterinary Science, 61242 Brno
}

Received October 16, 1990

\begin{abstract}
Tichý F.: The Morphogenesis of Circumvallate Papillae and the Differentiation of Taste Buds in the Porcine Foetus from Day 76 till Birth and in the Adult Pig. Acta vet. Brno, 60, 1991: $307-315$.

The development and morphology of some lingual structures were studied in the tongues of porcine foetuses at 76, 81 and 94 days after fertilization, of piglets 2 days after birth and of adult pigs. Special attention was given to the morphogenesis of circumvallate papillae and the differentiation of taste buds in papillary epithelium. The formation of the other types of papillae, and the development of the lamina propria mucosae and the related structures were also investigated.

Taste buds prevailed in the wall epithelium of the circumvallate papilla, while in its dorsal surface they occurred only occasionally during the first stages of the period studied. The amount of taste buds increased gradually in foliate papillae. In the period under study taste buds showed distinct differentiation of their cells.

The porus gustatorius formed immediately after the taste bud reached the surface of epithelium.

"Secondary" ducts of the gll. gustatoriae observed in circumvallate papillae in the late prenatal periods were present till birth.

The development of the other lingual papillae followed that of circumvallate papillae.
\end{abstract}

Tongue, papillae, taste bud, development, swine

The structure and composition of lingual mucosa is well understood at the levels of both light and electron microscopy. The basic information on the structure of the taste organ, based on electron microscopic observations, in laboratory animals as well as in man was reported early in this century (Kolmer 1910; Retzius 1912; Heidenhain 1914).

The result of a number of investigations into the ultrastructure of taste buds in some animal species (Beidler and Smallman 1965; De Lorenzo 1958; Farbman 1965a, Farbman and Tonkers 1971; Fujimoto and Murray 1970; Murray 1969, 1971, 1973; Murray and Murray 1960, 1967, 1970; Murray, Murray and Fujimoto 1969; Takeda and Hoshino 1975; Uga 1966, 1969 and others) contributed significantly to the understanding of taste perception mechanisms. They provided grounds for the development of methods for studying biochemistry and physiology of taste perception (Beidler 1970; De Han and Graziadei 1971; 1973; Hirata and Nada 1975; Spoendlin 1970; Takeda 1976; Beauchamp and Cowart 1986, and others).

Attention has also been paid to the development of the taste organ in man and various mammalian species (Bredler and Smallman 1965; Farbman 1965b, 1971; Takeda 1972 and others).

Less information is available on the development of mucosal structures of the tongue in relation to periods of development in farm animals. Particularly poor are data on the time of commencement of taste buds and on the changes in the gustatory receptor occurring during ontogenesis. 
The observations presented here are a continuation of the results published earlier (Tichy and Černý 1987, Tíchý 1990) concerning the process of maturation of porcine lingual mucosa and its characterization in selected periods of the pig's development.

\section{Materials and Methods}

Tongue samples for the study were collected from porcine foetuses at 76,81 and 94 days after fertilization, from piglets at 2 days after birth and from adult pigs aged 730 days. Age in foetuses was estimated by their crown-rump length (Evans nd Sack 1973).

From each age category three animals were sampled. The tissue was excised from the following areas of the tongue: junction of the body and root, lateral part of the root and apical dorsum linguae.

The collected material was immediately fixed in $10 \%$ neutral formaldehyde, then dehydrated in a graded series of alcohol (Tich ý 1991). The sections were stained with haematoxylin and eosin. Some sections were impregnated using the method of Gomori followed by staining with nuclear red. Sections intended for study of collagenous tissue were stained with the green trichrome reagent.

\section{Results}

\section{Lingual mucosa at 76 days of foetal age (Plate I., Fig. 1)}

The surface of the dorsum linguae bore many papillae, the most prominent being the well-developed circumvallate papillae. The other discernible forms were papillae fungiformes and papillae conicae. The lateral surface of the tongue root showed signs of developing papillae foliatae. They presented as inconspicuous folds slightly projecting above the surrounding mucosal surface.

Papillae vallatae were the most marked structures on the dorsum linguae. The surface of each of them included knob-like elevations of varying size, grooves and depressions. In cross sections it could be seen that from the bottoms of depressions tubular passages extended down to the connective and muscular base of the tongue to connect with the secretory parts of the gll. gustatoriae. The lumina of these "secondary" ducts, although large, were distinctly smaller than those of the true orifices of the gustatory glands.

The anlages of fungiform papillae were well differentiated in terms of shape, particularly in the vicinity of papillae vallate. Near the apex linguae, the anlages of conical papillae could be seen clearly but those of fungiform papillae were less distinct.

By this stage, the epithelium of the dorsum linguae had attained its definite appearance. The surface of differentiated papillae contained two or three layers of keratinized cells.

The anlages of foliate papillae on the lateral dorsum linguae presented as solid columns of connective tissue covered with stratified epithelium. The stratum germinativum of the epithelium was made up of two to three layers of small cells with hyperchromatic nuclei. The surface parts were formed by large polyedric cells with poorly stained cytoplasm. Signs of keratinization in the surface epithelial layer were observed only on the dorsal part of the commencing foliate papillae and the epithelium around them was much less differentiated than that of the other lingual mucosa.

Taste buds at various stages of development were found in the epithelium of the dorsum linguae and of the walls of circumvallate papillae. The buds had a typical shape and their apical section was connected with the epithelial surface. The porus gustatorius was not present. However, the differentiation of the bud 
cells into two types was quite apparent: these were cells with polychromatin nuclei and those with low-content chromatin nuclei. The epithelial cells close to the taste bud were spindle-shaped, as were their nuclei.

The anlages of foliate papillae contained taste buds only in the epithelial dorsal surface. Their appearance and the state of differentiation were comparable with those of the buds on papillae vallatae.

The lamina propria mucosae consisted of thin vascularized connective tissue. A dense connective band, the rudiment of the aponeurosis linguae, could be seen clearly even on the lateral margin of the tongue, particularly under the bases of foliate papillae.

\section{Lingual mucosa at 81 days of foetal age (Plate II., Fig. 2).}

Each type of papillae was well developed in this period and the appearance of mucosa on the dorsum linguae did not show any differences from that observed in the foetus 72 days old.

The dominant structure on the lateral margins of the tongue were differentiating foliate papillae in the shape of large ridges protruding above the adjacent mucosa. The anlages of the papillae, as seen in cross sections, were covered with stratified squamous epithelium, with signs of keratinization in its upper layers. Compared to that, epithelium of the mucosa around the papilla was much less differentiated, consisting of large polyedric cells with poorly stained cytoplasm.

In the foliate papilla, the epithelium of the dorsal surface and of the walls contained well formed taste buds in numbers much larger than in the 76-day-old foetus. Usually, the buds passed through the entire thickness of the epithelium and their apical parts reached the surface. Occasionally, the porus gustatorius was present. A clear differentiation into two bud cell types was evident.

The stage of differentiation, the distribution and density of taste buds in the epithelium of circumvallate papillae did not differ from those described in the previous age category; similar were also the findings concerning the lamina propria mucosae and the aponeurosis linguae.

\section{Lingual mucosa at 94 days of foetal age (Plate III., Figs 3 and 4)}

The most conspicuous structures on the mucosa of the dorsum linguae in this period were big circumvallate papillae surrounded with broad encircling furrows. Fungiform papillae had also differentiated in shape and were found mostly near circumvallate papillae towards the midline of the tongue.

The lateral surface of the tongue root showed high ridges of foliate papillae. The mucosa of the dorsum linguae typically consisted of stratified squamous epithelium with a thin layer of keratinized cells on the surface; epithelium of the lateral surface had a similar appearance.

A cross-sectioned circumvallate papilla was a large structure with a very uneven dorsal surface due to the presence of variously deep depressions and knob-like projections. Thin tubular canals lined with flat or low cuboidal epithelium opened on to the bottom of some of the depressions. They were connected, in deeper layers of the mucosa, to secretory regions of the gll. gustatoriae. These "secondary" ducts of gustatory glands were found regularly, and occasionally, in large depressions, even several openings could be seen. Taste buds were a rare finding in the dorsal epithelium of the circumvallate papilla; if present, they occurred at the transition of the dorsal surface to the wall of the papilla. The epithelium of the wall, on the other hand, showed a great number of taste buds. However, 
neither the buds nor their rudiments ever appeared in the walls of the deep depressions containing openings of the "secondary" ducts of gll. gustatoriae.

As a rule, taste buds were observed in the epithelium of the dorsal surfaces of the fungiform papillae which were in the close vicinity of a circumvallate papilla.

There was a clear distinction between the cells with hyperchromatin nuclei and those with hypochromatin nuclei in the taste bud. The porus gustatorius was a regular finding.

The differentiation, distribution and density of taste buds on foliate papillae corresponded to those recorded in the previous age group.

The lamina propria mucosae was well vascularized and, in its lower parts, contained numerous secretory regions of the gll. gustatoriae.

\section{Lingual mucosa in piglets 2 days after birth (Plate III., Fig. 5)}

The papillae on the lingual mucosa at this age had a usual appearance. The most conspicuous structures were circumvallate papillae which in size and shape corresponded to those described in foetuses 94 days old. The only difference observed was that the encircling furrow was larger and more open.

The dorsal surface of the circumvallate papilla was covered with many small knob-like projections and depressions that did not extend into the connective stroma of the papilla as far as was seen in the previous period; the depressions looked like shallow pits.

Foliate papillae had attained the definite appearance of long, high ridges on the lateral walls of the tongue root.

A cross section through the lingual mucosa showed stratified squamous epithelium with keratinized upper layers.

The connective stroma of the circumvallate papillae showed numerous wide tubular passages perpendicular to the dorsum of the papilla. Their openings could not be seen; in most cases their blind ends finished under the germinative epithelial layer. These "secondary" ducts of gll. gustatoriae were much larger than in the previous age category and their lumina were comparable with those of the definite ducts opening onto the bottom of the encircling furrow. Duct lining was composed of one to two strata of low epithelium.

Taste buds were present only in the wall epithelium of circumvallate papillae and in the epithelium of foliate papillae. The buds in both papillae were similar in appearance and their cells were differentiated to the same extent. The porus gustatorius was a regular finding.

The lamina propria mucosae contained secretory regions of gll. gustatoriae with numerous orifices seen in cross sections.

\section{Lingual mucosa in the adult pig aged 730 days (Plate III., Fig. 6)}

The mucosa on the dorsum linguae in the adult pig showed all the usual papillae in their definite shape, size and structure. The differences, as compared with the previous age group, were only in size and extent.

In cross-sectioned mucosa, the largest structures were circumvallate papillae whose dorsal surfaces were composed of many knob-like elevations and shallow pits. In the connective stroma, "secondary" ducts of gll. gustatoriae were no longer present.

Taste buds were situated in the walls of the circumvallate papilla and their gustatory pores opened into the encircling furrow. The distribution and density 
of taste buds on foliate papillae were similar to those found in the previous age category.

The lamina propria mucosae showed numerous secretory regions of gll. gustatoriae, sectioned orifices and small lymphocyte infiltrates.

\section{Discussion}

Our observations of the lingual mucosa in the pig show that the process of differentiation was taking place throughout the whole period studied. The changes recorded here relate to the findings published earlier (Tichý 1990) on the differentiation processes in the lingual mucosa of porcine foetuses between the 41st and 64th days of prenatal development.

In the foetus at 76 days, the cells of taste buds are distinctly differentiated into two basic types i. e., sensory cells and supporting cells. Details of their morphology and descriptions of the other cell types involved in the taste bud have been reported in a number of studies based on electron-microscopic observations (Farbman 1965 a, b; Gray and Watkins 1965; Graziadei 1969; Murray 1971; 1973; Murray, Murray and Fujimoto 1969; Takeda 1972; Takeda and Hoshino 1975; Uga 1966, 1969). It can thus be concluded that the differentiation leading to the definite structure of the taste bud is finished by the 76th day and further maturation processes produce only changes in size and localization.

While the frequent occurrence of taste buds in the dorsal epithelium of a developing circumvallate papilla is a typical feature of the initial stages of lingual mucosa development (Tichý and Cerný 1987; Tichý 1990), from the 76th day on, the bud presence on the dorsum is an exceptional finding and taste buds are situated mostly in epithelium of the wall. The change in taste bud position seems to be related to progressive growth of the circumvallate papilla in this period (Tichý and Černý 1987).

Taste buds reach the surface of lingual epithelium as early as at 76 days but gustatory pores were not found before 81 days. This indicates that the time between 76 and 81 days is a period during which the taste buds in epithelium of the circumvallate papilla attain their definite appearance.

The number of buds found on rudiments of foliate papillae was lower than that observed in circumvallate papillae at the beginning of the period studied. This is in agreement with a finding that the commencement of taste buds in epithelium occurred later in foliate papillae (day 57) than in circumvallate papillae (day 50) (Tichý 1990). These observations imply that the differentiation of taste buds in foliate papillae is at a lower level than in circumvallate papillae. The lag in the development of buds within the foliate papilla corresponds to the fact that, in the given period, the stage of lingual mucosa differentiation is regularly lower on the lateral surface than on the dorsum linguae (Tichý 1990). It is of interest that a similar difference in differentiation between lateral and medial arrays of circumvallate papillae has been recorded earlier in sheep (Tichý and Černý 1987). If we accept the view that the commencement and development of taste buds is directly related to the innervation of mucosa (Farbman $1965 \mathrm{a}, \mathrm{b}$; Murray and Murray 1967; Takeda 1976) then the lateral parts of the tongue are supplied with nerves later than the dorsum linguae. However, it is also possible, and in our opinion even more likely, that the maturation of the lateral part of 
lingual mucosa occurs generally later than that of the dorsal part; the lower level of differentiation in taste buds on foliate papillae only makes the lag evident.

In fungiform papillae, taste buds were found in epithelium as late as at 94 days of prenatal development. If we assume, together with some other authors (Fujimoto and Murray 1970; Kurosumi et al. 1969; Munger 1965; Spoendlin 1970; Takeda and Hoshino 1975, and others), that the site for commencement of a bud is determined by a contact of epithelial cells with a nerve fibre, then, out of the three types of sensory papillae, the fungiform papillae will be the last to be innervated.

An interesting finding was the presence of the „secondary“ openings of gll. gustatoriae among the segments of the composite base early in development (day 57) which persisted until after the papilla produced a unified structure (day 64) (Tichy 1990). Our observations showed that the openings still existed at 2 days after birth. Their continuation with the dorsum of the circumvallate papilla was evident between 76 and 94 days of prenatal development. In this period the openings ended in deep depressions created in the surface of mucosa on the circumvallate papilla. The epithelium near these openings never showed any taste buds, which makes it difficult to find a reason for the existence of the openings. These obviously disappeared after birth because the place of their connection with the surface of circumvallate papillae could not be demonstrated. Their disappearance seems related to the fact that after birth the "secondary" ducts of gll. gustatoriae evolved into spacious cavities deposited in the connective tissue of the circumvallate papilla stroma.

In the interval studied, the absence of the rudiment of aponeurosis linguae under the bases of circumvallate papillae was a persistent finding. This supports our view published earlier (Tichý 1990) that, as a results of disruption in continuity of the aponeurosis linguae to the extent found here, the development of gll. gustatoriae ducts is "made easier".

Since no detailed study on the development of lingual mucosa in the late prenatal and early postnatal periods has been reported, the results are presented here as a contribution to the understanding of the maturation processes in the tongue of swine.

\section{Conclusions}

The study is concerned with the development of the lingual mucosa in the pig from 76 days before birth to 2 days after birth. Attention is given to the morphology of circumvallate papillae and the differentiation of taste buds in epithelium. For the sake of completeness, a description of this area of lingual mucosa in adult pigs is also presented. For the period studied the following conclusions can be drawn:

1. Taste buds are formed in the epithelium of circumvallate papillae. They occur particularly in epithelium of the walls while on the dorsum their presence is only occasional; from day 94 on, they are absent.

2. The epithelium of foliate papillae shows a frequent occurrence of taste buds at 81 days of development.

3. The cells composing taste buds are clearly differentiated as early as at 76 days.

4. Taste buds reach the surface epithelium at 76 days; at 81 days most of the buds have gustatory pores.

5. In fungiform papillae, taste buds appear in epithelium at 94 days. 
6. Circumvallate papillae are the most prominent structures on the surface mucosa of the tongue. Their dorsal surfaces are broken into depressions varying in depth; these are apparent in the period between 76 and 94 days. After birth the unevenness of the surface is not so marked. "Secondary" ducts of gll. gustatoriae open into some of the depressions and persist till 2 days after birth.

7. Foliate papillae differentiate in shape from the 76th till the 81st day. Any later changes involve only size of the papilla.

8. The morphogenesis of the other types of lingual papillae begins with the 76th day.

9. The rudiment of aponeurosis linguae is not present under the bases of circumvallate papillae.

Morfogeneze hrazené papily a diferenciace chutových pohárků fetu prasete od 76. dne do narození a dospělého jedince

Na vzorcích jazyka fetů prasete ve stáři 76,81 a 94 dnů po koncepci, jazyka selete 2 dny po porodu a jazyka dospělého jedince byl sledován vývoj a vzhled některých struktur sliznice se zretelem na morfogenezi hrazených papil a diferenciaci chutových pohárků $v$ jejich epitelu. Pozornost byla současně věnována utváření dalšich typů jazykových papil, vývoji lamina propria mucosae a $\mathrm{v}$ ní uložených struktur.

Chutové pohárky jsou lokalizovány $\mathrm{v}$ epitelu stěny hrazené papily, $\mathrm{v}$ epitelu dorsální plochy jsou uloženy jen ojediněle pouze $\mathrm{v}$ prvních stadiích sledovaného období. Postupně se zvyšuje počet pohárkư v rozsahu papil lístkovitých. Ve sledovaném období jsou buňky chutových pohárkủ zřetelně diferencované $\mathrm{v}$ jednotlivé typy.

Porus gustatorius se vytvárí v období těsně po kontaktu pohárku s povrchem epitelu.

$\mathrm{Na}$ hrazených papilách přetrvávaji „sekundárni“" vývody gll. gustatoriae až do narozeni.

Ostatni typy papil se vytvářejí později než papily hrazené.

\section{Морфогенез желобоватого сосочка и дифференциация вкүсовых пүковиц плода свиньи с 76 сүток до опороса и взроспой особи}

На образцах языка плодов свиньи в возрасте 76, 81 и 94 сүток после зачатия, языка поросенка 2 сүток после опороса и языка взрослой особи проводили исследование развития и внешнего вида некоторых структур слизистой оболочки с учетом морфогенеза желобоватых сосочков и дифференциации вкусовых луковиц в их эпителии. Одновременно уделили внимание образованию других типов сосочков языка, развитию lamina propria mucosae и расположенных в .ней структур. Вкусовые пуковицы расположены в эпителии стенки желобоватого сосочка, в эпители дорсальной поверхности они встречаются лишь в единичных случаях, только на первых стадиях исследуемого периода. Постепенно возрастает численность лүковиц в пределах листовидных сосочков. В исследуемый период наблюдается четная дифференциация вкусовых луковиц по отдельным типам. 
Porus gustatorius образуется непосредственно в период контакта пуковицы с поверхностью эпителия.

На желобоватых сосочка до самого рождения остаются «вторичные» протоки gll. gustatoriae.

Образование остальных типов сосочков происходит позже желобоватых сосочков.

\section{References}

BEAUCHAMP, G. K.-COWART, B. J.: Development of Sweet Taste Sweetness. Ilsi human nutrition Reviews, Symp. on Sweetness, Geneva, Switzerland, May 21-23, 1986: 127-130

BEIDLER, J. M. - SMALLMAN, R. L.: Renewal of cells within taste buds. J. Cell Biol., 27, 1965: $263-272$

BEIDLER, J. M.: Physiological properties of mammalian taste receptors. In: Taste and smell in vertebrates. Wolstenholme and Knight, eds. Ciba Found. Symp. London, J. A. Churchill, 1970: $51-67$

DE HAN, R.-GRAZIADEI, P. P. C.: Functional anatomy of frog's taste organs. Experientia, 27, 1971: 823-826

DE HAN, R. - GRAZIADEI, P. P. C.: The innervation of frog's taste organ. "A histochemical study". Life Sci., 13, 1973: $1435-1449$

DE LORENZO, A. J.: Electron microscopic observation on the taste buds of the rabbit. J. Biophysic. Biochemic. Cytol., 4, 1958: 143-150

EVANS, H. E. - SACK, W. O.: Prenatal development of domestic laboratory mammals. Growth curves, external features and selected references. Zbl. Vet. Med., Reihe C, 2, 1973: 11-45

FARBMAN, A. I.: Fine structure of the taste bud. J. Ultrastruct. Res., 12, 1965a: 328-350

FARBMAN, A. I.: Electron microscope study of the developing taste bud in rat fungiform papilla. Devel. Biol., 11, 1965b: 110-135

FARBMAN, A. I.: Development of the taste bud. In: L. M. Beidler (Ed.) Handbook of sensory Physiology, Vol. IV., Chemical Senses, Part 2, Springer, New York, 1971, 51-62

FARBMAN, A. I. - YONKERS, J. D.: Fine structure of the taste bud in the mud puppy, Necturus maculosus. Amer. J. Anat. 131, 1971: 353-370

FUJIMOTO, S.-MURRAY, R. G.: Fine structure of degeneration and regeneration in denervated rabbit vallate taste buds. Anat. Rec., 168, 1970: 393-414

GRAY, E. G.-WATKINS, K. C.: Electron microscopy of taste buds of the rat. Z. Zellforsch., 66, 1965: 583-595

GRAZIADEI, P. P. C.: The ultrastructure of vertebrate taste buds. In: (ed. by) C. Pfaffmann: Olfaction and taste, New York, Rockefeller University, 1969, 315-330

HEIDENHAIN, M.: Ưber die Sinnesfelder und die Geschmacksknospen der papilla foliata des Kaninchens. Arch. mikr. Anat., 85, 1914: 365-479

HIRATA, K. -NADA, O.: A monoamine in the gustatory cell of the frog's taste organ. Cell Tiss. Res., 159, 1975: $101-108$

KOLMER, W.: Uber Strukturen im Epithel des Sinnesorgane. Anat. Anz., 36, 1910: 281-299

KUROSUMI, K.-KUROSUMI, U.-SUZUKI, H.: Fine structures of Merkel cells and associated nerve fibers in the epidermis of certain mammalian species. Arch. histol. jap., 30, 1969: $295-313$

MUNGER, B. L.: The intraepidermal innervation of the snout skin of the opossum. A light and electron microscope study, with observations on the nature of Merkel's Tastzellen. J. Cell Biol., 26, 1965: 79-97

MURRAY, R. G.: Cell tapes in rabbit taste buds. In: Olfaction and taste III, Pfaffman, ed. New York, Rockefeller Univ. Press, 1969: $331-344$

MURRAY, R. G.: Ultrastructure of taste receptors. In: Handbook of sensory physiology, vol. IV Chemical sẻnses, part 2 Taste, Beidler, ed. Berlin-Heidelberg-New York: Springer, 1971: $31-50$

MURRAY, R. G.: The structure of taste buds. In: Ultrastructure of sensory organ, vol. 1, Friedman, ed. Amsterdam: North Holland, 1973: 1-81

MURRAY, R. G.-MURRAY, A.: The fine structure of the taste buds of Rhesus and Cynomolgus monkeys. Anat. Rec., 138, 1960: 211-233

MURRAY, R. G.-MURRAY, A.: Fine structure of taste buds of rabbit foliate papillae. J. Ultrastr. Res., 19, 1967: 327-353 
MURRAY, R. G.-MURRAY, A.: The anatomy and ultrastructure of taste endings. In: (ed. by) G. E. W. Wolstenholme und J. Knight: Taste and smell in vertebrates. London, J. and A. Churchil, 1970: 3-30

MURRAY, R. G.-MURRAY, A.-FUJIMOTO, S.: Fine structure of gustatory cells in rabbit taste buds. J. Ultrastr. Res., 27, 1969: 444-461

RETZIUS, G.: Zur Kenntniss des Geschmackorgans beim Kaninchen. Biol. Untersuch., n. f. 17, 1912: 72-113

SPOENDLIN, H.: Taste buds. In: (ed. by) A. Bischoff: Ultrastructure of the peripheral nervous system and sense organs. Stuttgart, Georg Thieme Verlag, 1970: 326-337

TAKEDA, M.: Fine structure of developing taste buds in human fetal circumvallate papillae (in Japanese with English summary). Acta anat. nippon., 47, 1972: 325-337

TAKEDA, M.: An electron microscopic study on the innervation in the taste buds of the mouse circumvallate papillae. Arch. histol. jap., 39, 1976: 257-269

TAKEDA, M.-HOSHINO, T.: Fine structure of taste buds in the rat. Arch. histol. jap., 37, 1975: $395-413$

TICHY, F.: The Morphogenesis of Circumvallate Papillae and the Differentiation of Taste Buds in the Pig at 41 to 64 Days of Prenatal Development. Acta vet. Brno, 60, 1991: 99-110

TICHÝ, F.-CERNYY, H.: The morphogenesis of circumvallate papillae and differentiation of taste buds in sheep ontogeny. Acta vet. Brno, 56, 1987: 261-274

UGA, S.: The fine structure of gustatory receptors and their synapses in frog's tongue. Symp. Cell Chem., 16, 1966: 75-86

UGA, S.: A study on the cytoarchitecture of taste buds of rat circumvallate papillae. Arch. histol. jap., 31, 1969: 59-72 
Plate I.

Tichý F.: The Morphogenesis... pp. 307-315

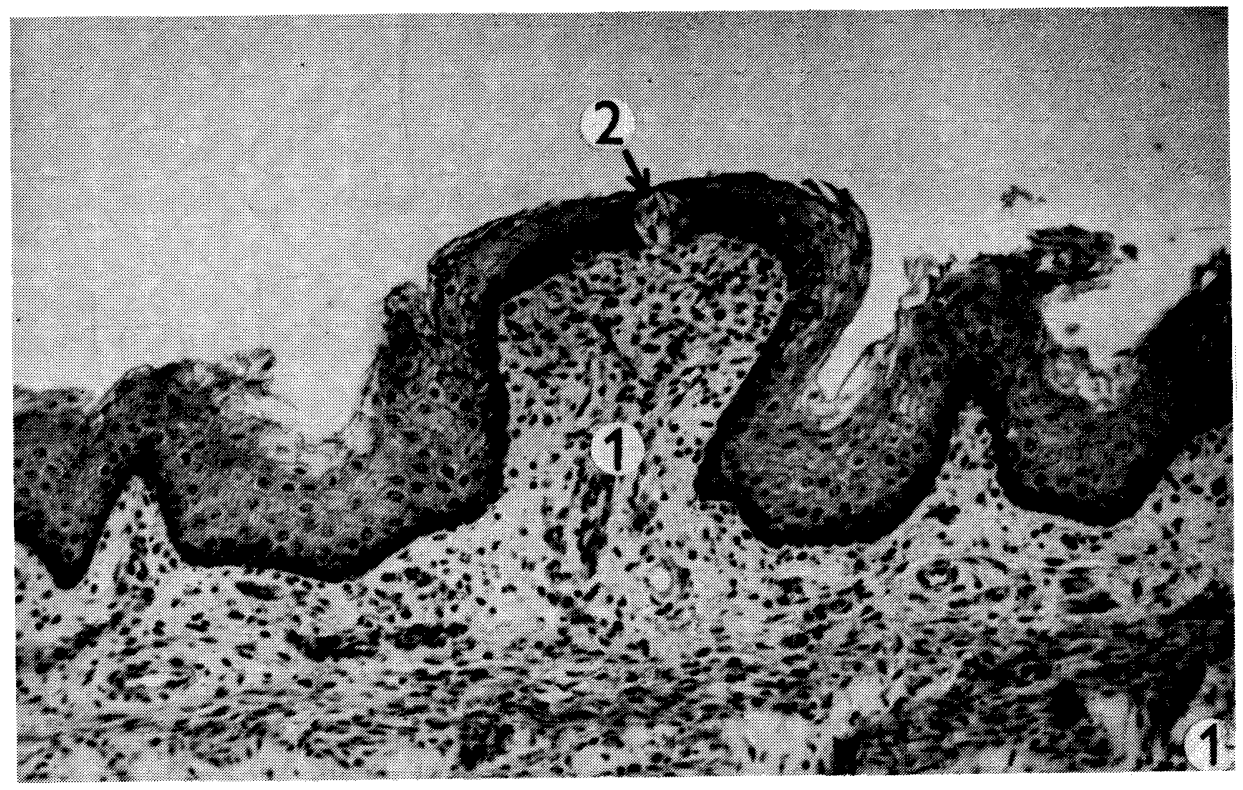

Fig. 1. Part of the lateral dorsum linguae in a pig foetus at 76 days. Developing foliate papilla (1) with a taste bud on its dorsal surface (2). HE, $\times 250$.

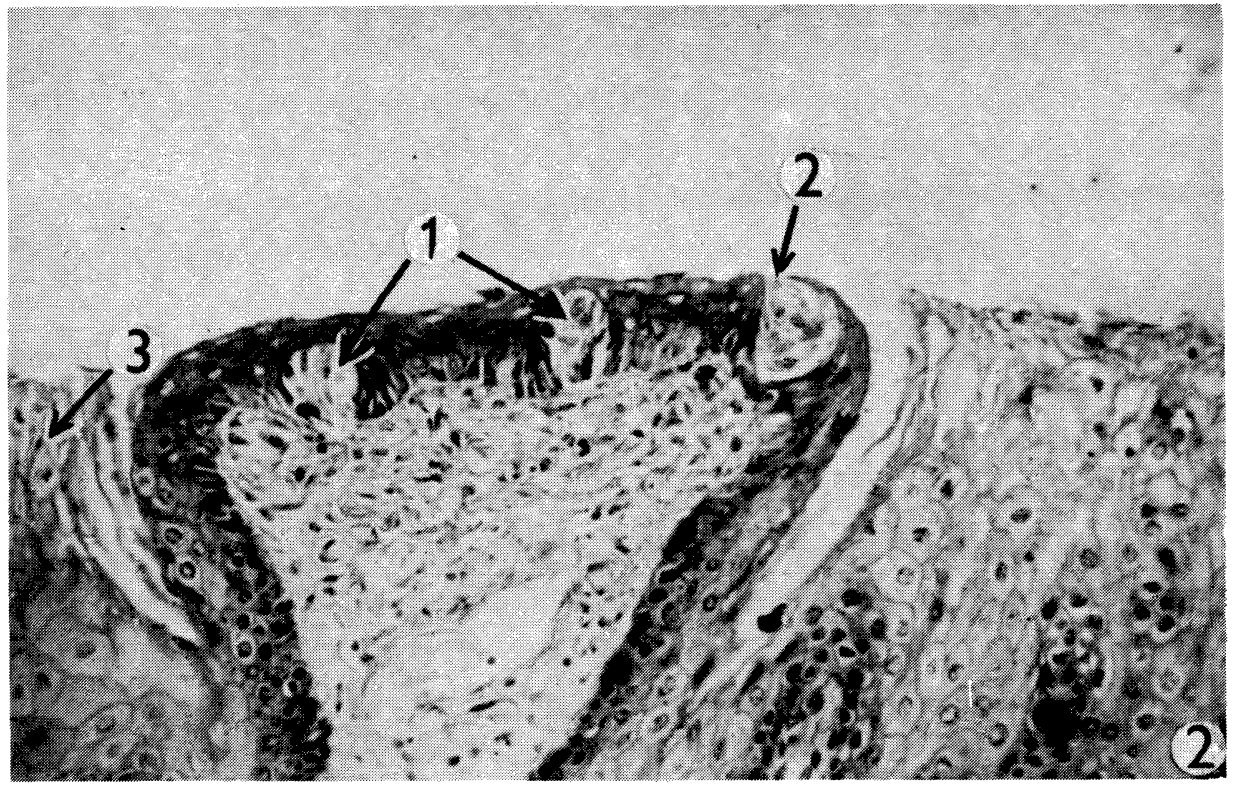

Fig. 2. Tangential section through the anlage of a foliate papilla in an 81-day-old porcine foetus. Taste buds in epithelium (1), an open porus gustatorius (2). Light cells of the surrounding epithelium (3). HE, $\times 400$. 
Plate II.

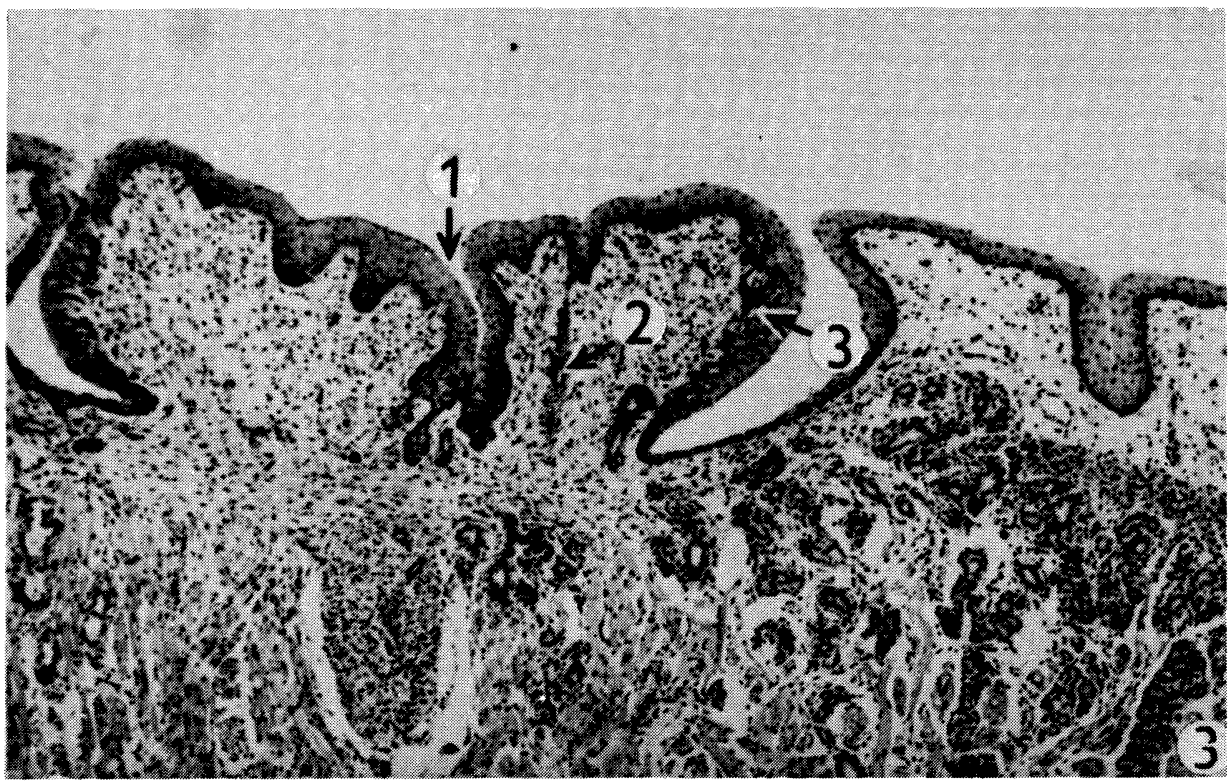

Fig. 3. A circumvallate papilla on the tongue of a porcine foetus at 94 days. A deep depression in the dorsal surface of the papilla (1) with openings of the "secondary" ducts of gll. gustatoriae. A cross-sectioned "secondary" duct of gll. gustatoriae (2) in connective stroma of the papilla. Taste buds in the wall epithelium of the circumvallate papilla (3). HE, $\times 100$.

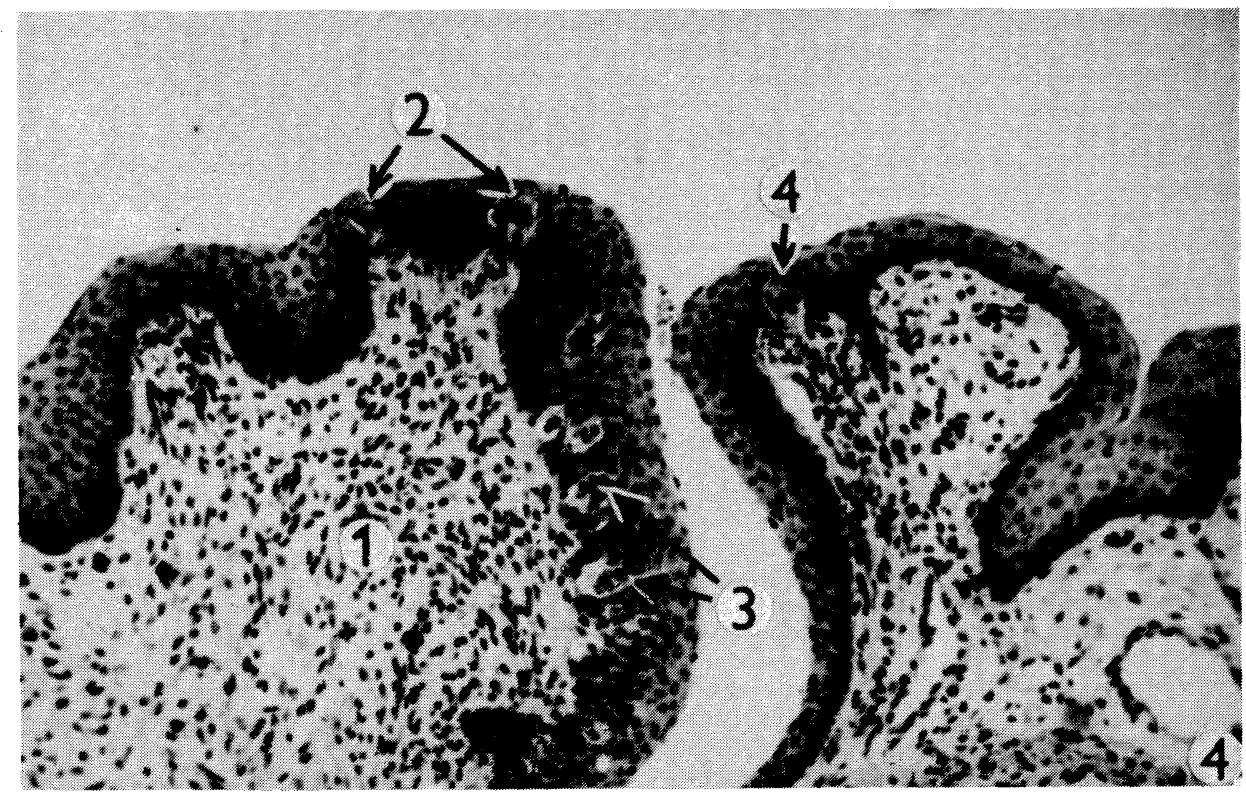

Fig. 4.. Part of a circumvallate papilla (1) on the tongue of a 94-day-old porcine foetus. Taste buds in marginal epithelium of the dorsal surface (2) and in wall epithelium (3). A taste bud in a fungiform papilla (4). $\mathrm{HE}, \times 250$. 


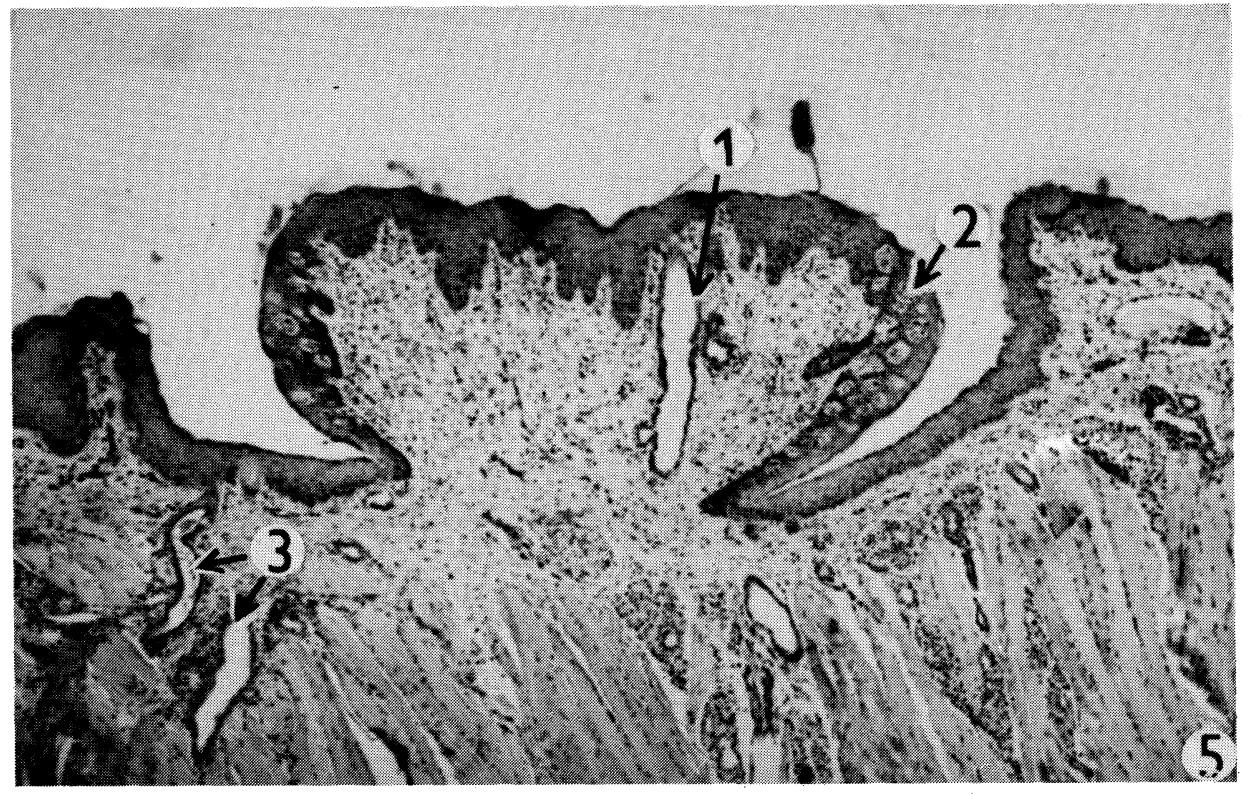

Fig. 5. Circumvallate papilla on the tongue of a piglet two days after birth. A cross section through a still existing "secondary" duct of gll. gustatoriae (1). Taste buds in the wall of the papilla (2). $\mathrm{HE}, \times 100$.

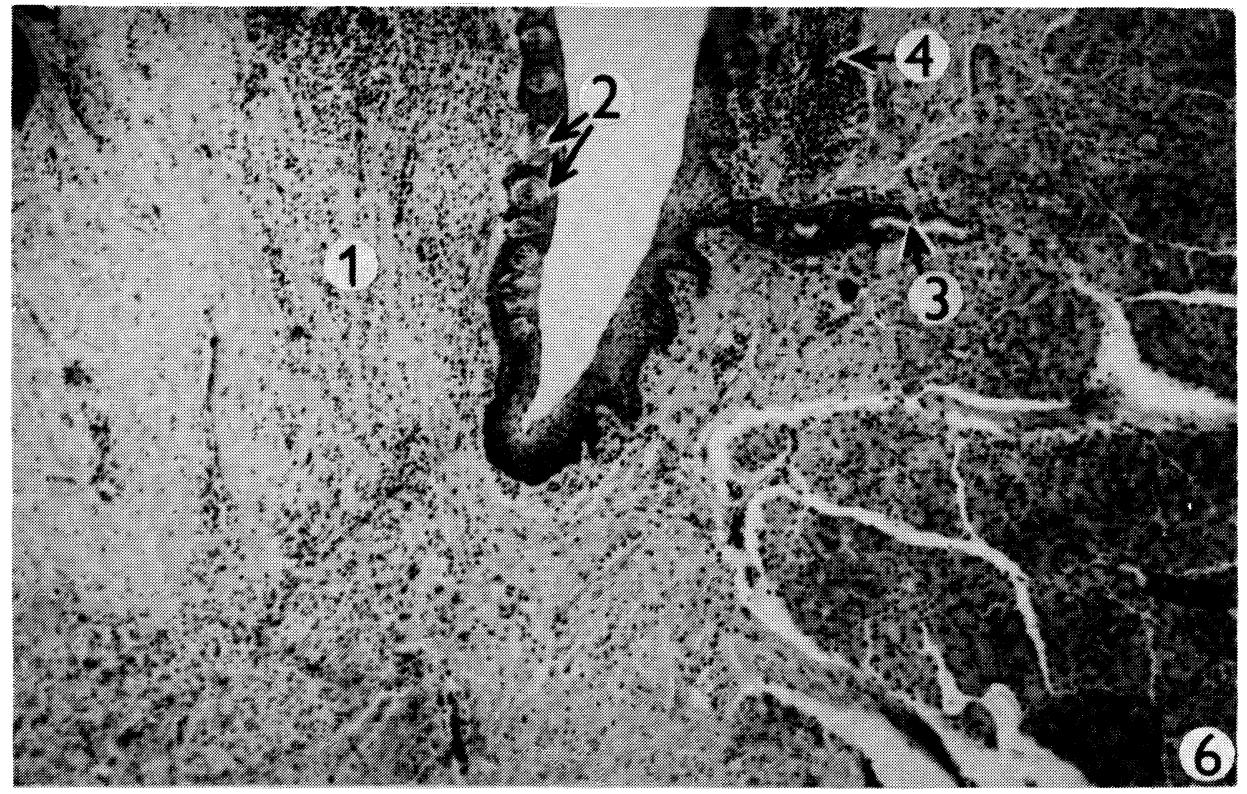

Fig. 6. The basal part of a circumvallate papilla in an adult pig (1). Taste buds in epithelium (2). A cross-section through a duct of gll. gustatoriae in the lamina propria mucosae (3). Lymphocyte infiltrate in connective tissue. HE, $\times 250$. 